\section{NATURAL HISTORY NOTES FROM SOUTH} $A F R T C A$

W R. J. P. MANSELL, of Brooklyn, near King W William's Town, Kaffraria, has sent us the following notes, the results of his own observation in the district in which he dwells :-

In November 1869 I was looking for some louries in the Bedford forest. My gun was loaded with a very small charge of dust shot. A large troop of monkeys was disturbing my birds, and, annoyed with them, I fired among them at random. One fell on the branches of a bush, shrieking piteously. I ran up to put the poor thing out of its agony, when to my great surprise I saw the whole troop (about twenty) rushing down the trees and screaming savagely. They came so close to me that I had some trouble in killing the wounded one, as I was afraid they would attack me. Were monkeys substituted for toucans in the frontispiece to Mr. Bates's Travels, the scene would be almost identical.

A few days ago, while working in my garden, my attention was drawn to a part of the kloof by the angry screams of birds, indicating a snake. On approaching the spot where the birds were collected, I noticed several dashing at a low shrub. As I approached the dark underwood an Ahætulla, whose characters do not agree with any published description, rushed out. I struck it with a spade, and then, curious to see how the birds would act, I flung it half alive over a branch of a tree, still holding it by the tail.

There were a great many bush birds, but especially noticcable were Turdus olivacezs and a Campephaga.

The first-mentioned birds kept fiying round in a wide circle, dashing with open wing and beak at the snake, and screaming with the utmost fury. With such violence did these birds dash at their enemy, that more than once the bird fell on the ground from the branch against which it struck. The birds continued attacking the snake for some minutes.

While at the Koonap in 1865 I saw the common Fuida phonicoptera, which had a nest in the trunk of an Euphorbia, screaming with fury, and attacking boldly a red mierkatje, which was endeavouring to plunder its nest.

We have heard so much of the mysteries of fascination, $\& c$, that I think a comparison of the cases I have given, together with the well-known way in which birds pursue owls, cats, and cuckoos, shows that it is more fear than anger which gives the subtle snake an easy prey, than any mysterious mesmeric influence; and I believe the immunity of the mongoose from the poison is owing to its closely-pressed, tight, wiry hair.

The wattles of turkey-cocks are a decided disadvantage to them in a warm comnty like this. I have lost two from the Alies laying their eggs in the wounds inflicted by rival birds.

Some four or five years ago, when in Fort Beaufort, a friend of mine amused me by bringing a stuffed leopard to a pet monkey he had. The monkey would scream with terror, shut its eyes, and hide away in my friend's coat. On touching it with the claws its terror was piteous. On removing the leopard it would slowly peep out, and on catching sight of it close its eyes tight.

I do not think it is yenerally known that baboons in Karoo districts, such as Richmond and Hopetown, destroy in dry seasons numbers of lambs. A farmer told me that they were more destructive than any other wild animal in the district.

There are likewise two varieties of the leopard called respectively Berg and Rivière Tiger, from frequenting mountains or rivers; and the baboons are said to vary according to their locality. It is said that baboons will kill a leopard. A friend of mine at the Koonap had a tame baboon which shouldered arms and wrapped itself in a sheepskin like a Kafir.
South Afrian Bints which eat Butcrfties.-As some doubt was thrown on this subject in your journal a year ago, I now give the result of a year's careful observation, and I have little doubt the number could be greatly increased. Cypselus caffer eats Pieris hellica and Terias rahel, also numerous small Heterocera.

Zosterops capensis eats Pieridre and small moths. On April 30 , 1871, I saw a pair trying to capture a butterfly, which very cleverly eluded them.

Motacilla capensis-Pieridæ and moths, but prefers flies and bees.

Anthus capensis-Pieris hellica and P. charina.

Oriolus capensis - Pieris charina and $P$. gidica or P. severina.

Tchitrea cristata-Pieris agathina and other Pierida, and, I think, other butterflies too, but am not certain.

Dicrurzes musicus. I saw this bird dart at and capture last year so large and rapid a butterly as Philogroma varanes; it also destroys Pieridæ.

Lanizis collaris. I have seen this bird take butterflies, but do not know whether it is in sport or for food.

The above instances are from actual observation, made in some cases more than once.

Migrations of Insects and Plants.-I have especially remarked, since my attention was drawn to it, how few conspicuously coloured and hairy caterpillars are attacked by birds. Some of these conspicuous caterpillars, on being touched, eject a nauseous liquid in large quantities; this is especially the case with Antherea iyrrhea, the larva of which every year strips my thorn trees (Acacic horriala) quite bare. The eggs are large, enclosed in a hard, bluish white shell, and fastened in large clusters at the end of branches. They appear to be never destroyed by animals.

The moth generally issues in abundance after the first heavy warm rains of September or October, and is seldom to be found after a week. This is also the case with several allied moths. Hundreds may then be seen like small bats, and the next morning the ground is often strewed with their fragments, as they appear to be highly attractive to nocturnal birds. The larva is often attacked by ichneumons, but still the quantity is unappreciably diminished, and hundreds may be seen travelling from tree to tree. They are more numerous in wet than dry seasons.

We have had this year some remarkable visitations of Pieridæ. In October, November, and December I have seen enormous swarms, principally composed of Pieris charina, severina, gidica, and hellica. The early part of the summer was very cool, but just before Christmas and at present the heat has been most oppressive. On December 24, I found the shady inside of the kloof alive with Pieris agathina, in all the varieties, as far as I could judge, principally males. This butterfly is usually abundant in September, but I had observed only a few specimens in the early summer.

I tried to make a calculation as to their numbers, and selected a damp spot where most of the insects had settled. I counted on a spot about three yards square about fifty; many were hidden by stones and leaves. They were about equally abundant in other parts of the kloof, and I think, therefore, that fifty would be a fair average. As the kloof is 500 yards long, or thereabouts, and in some parts thirty yards broad, I think the following calculation (allowing for the extra attractiveness of the moist spot observed), namely, twice the quantity, calculated at three yards broad, would give a quantity of I6,666 for the entire kloof. The kloof was full of birds chasing these insects, and two days later the number was greatly diminished.

As far as my observations go, I am led to believe that there are three kinds of migrations among butterflies. The principal relates, for the most part to Pieridæ, such as Pieris hellica, gidica, severina, mesentina, and Colius electra. These butterflies seem to be attracted to 
cultivated ground, old kraals, or cleared forest. On all these spots vast numbers of weeds-many introduced plants-spring up, and appear to be particularly attractive to these insects. These migrations take place as often against as with the wind.

Papilio merope, Philogroma varanes, Pieris eriphia, Pieris zochalia, and Terias rahel appear to migrate in the direction of the wind, and there are one or two others which perhaps do so also, such as funonia pelasgis. When resident at Bedford I never saw these butterflies in seasons of drought, but so soon as the southerly winds with rain became abundant a few stragglers might be met with.

$P$. gidica, mesentina, and severina likewise share in these southerly and northerly migrations.

Lastly, there are the sudden and almost inexplicable appearance and disappearance of certain species, such as Callidryas rhadia, Diadema misippus, \&c., although I see Mr. Bowker mentions having seen vast swarms of the former in the Drakensberg taking a south-easterly course. During the last two years I have hardly seen a specimen of these two butterflies. The year before they were most abundant. I would here remark that I do not remember to have noticed in any entomological work, although the shapes of butterfly wings are accurately described, an account of their peculiar and finely graduated modes of flight.

Thus, in Pieridr, $P$. hellica flies generally in open ground from flower to flower, but alternately rises and talls and shifts from side to side. Terias rahel has a similar flight, but slightly more direct; Colizs electra a similar flight, but I think a trifle swifter.

Cypselius caffer, which preys on these, generally describes semicircles, flying backwards and forwards over the grass in the manner of a scythe working, and it is curicus to see how artfully these butterflies, by a slightly higher or lower flight, escape their much swifter winged enemy.

The different varieties of $P$. agathina in like manner vary. The whiter specimens ( $\delta$ ) frequent more the open, and are a trifle swifter in their flight than the gamboge and ochreous varieties, or their o. The latter frequent wooded spots, and rise and fall through the foliage like dead leaves, and it is surprising to see how with sluggish movements a slight change of direction saves their lives. $P$. gidica, mesentina, severina, and zochalia in like manner vary among themselves in their varieties and in different localities.

I was particularly struck, when on a visit to Cradock in 1867 , by the difference of size and colour and flight in Mesentinas in the Karoo from that of those in the Bedford Forest.

Papilio cenea, which my observations confirm as being the fernale of merope, as so admirably indicated by $\mathrm{Mr}$. Trimen, changes its flight in a remarkable manner when quitting the forest for the open plain. In the forest its flight is remarkably weak, especially if contrasted with that of its mate ; whereas over open plains it rapidly rises out of sight, and soars away like some bird of prey with scarce a flutter of the wing.

Funonia pelasgis, archesia, and amestris are in like manner very similar in their flight, but differ with the difference of the localities they frequent; $\mathcal{F}$. archesia being intermediate between the forest-frequenting $\mathcal{F}$. pelasyis and the plain-loving $\mathcal{F}$. amestris. It is also remarkable that where $\mathcal{F}$. archesia frequents the same spots as F. pelasgis, its markings approach that species; where it delights in open country, about Kaffraria, it is bluer, and slightly more like 7 . amestris.

Nymphalis xiphares. - The $q$ of this species is much weaker in its flight than the male, and its coloration, as is known, differs remarkably. Last year I captured it in company with $P$. merope and $q P$. echerioiaes, and was much struck at the time by the similarity of colour and pattern, although its imitation is much coarser than that of the other two butterflies.

A long series of $\delta$ and $q$ Meropes shows a remarkable variation, hardly two specimens being alike, and in one $\delta$ a small oblong black spot closes the discoidal cell of the fore-wing.

On some occasions plants of different orders seem suddenly to increase and then almost disappear for a season or so. This is notably the case with some Compositæ.

As I mentioned in a letter to $\mathrm{Mr}$. Darwin, two species of Gramineæ, Tragus aliena and Brizu geniculata, appear to spring up in the course of locust swarms. I at first was rather sceptical on this subject, but by carefully watching the locusts and examining sour veld, where these grasses do not generally grow, I believe that the opinion of the farmer who first called my attention to it is correct.

Mr. Darwin, I believe, raised plants from locust dung which I sent him, but I am not aware to what species they belonged.*

\section{FEFFRIES WYMAN, M.D.}

$\mathrm{T}$ the death, on the 4 th ult, at Bethlehem, N.H., of Prof. Jeffries Wyman, American biological science has lost one of its most able comparative anatcmists. Prof. Wyman was born on Aug. I I, I8I4, at Chelinsford, Massachusetts, and had therefore just completed his sixtieth year. His father was a well-known physiciar. He graduated in Arts at Harvard University in 1833 , whereupon he commenced his medical education, and took his degree in 1837 , after which he for two years continued his studies in Paris. Returning to Boston he became for some time curator of the Lowell Institute, where he commenced his career as a teacher by delivering two courses of lectures on comparative anatomy and physiology, in which he first gave indications of the lucid and well-ordered expository powers which throughout his life made him so great a favourite with all hard-working students. In 1844 he became Professor of Aratomy and Physiology in the Medical School of Richmond, Virginia, in connection with the Hamden.Sidney College. In I 847 he succeeded Dr. Warren as Professor of Anatomy in Harvard University; at which time, from the materials brought from Africa by Dr. Savage, he had the earliest opportunity of describing that naturalist's new genus of anthropoid apes, the Gorilla (Troglodytes gorilla, Savage). This professorship he held till 1866 , and it is to him that Cambridge, Mass., almost entırely owes the development of its excellent Museum of Comparative Anatomy.

Prof. Wyman had for many years been a sufferer from phthisis, which necessitated his removing to the warmer climate of Florida during the winter months, and the cessation of his lectures and practical work. When the Peabody Museum of American Archæology and Ethnology was established, the founder appointed Prof. Wyman one of his trustees, and the board committed the incipient museum to his charge and direction. The seventh annual report of this institution, just issued, was his last production. Most of his written contributions to science are contained in the Journal and Proceedings of the Boston Natural History Society, of which for many years he was the president; and in the "Smithsonian Contributions to Knowledge."

Prof. Wyman was a man of singular modesty and truthfulness. His bad health was always in the way of his will to work ; and his desire of completely mastering whatever he undertook, together with a certain overcautiousness, has limited the number of his works. It is not remembered that he ever had a controversy. In his death a gap has been caused which it will be difficult to fill.

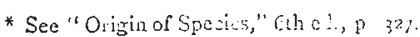

